\section{The Emperor's new theory}

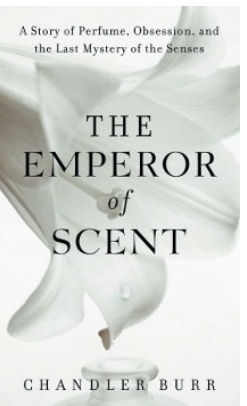

\section{The Emperor of Scent: A Story of Perfume, Obsession, and the Last Mystery of the Senses}

\author{
by Chandler Burr \\ Random House, New York, $2002 \$ 24.95$ \\ hardcover, pp 318 \\ ISBN 0-375-50797-3 \\ Reviewed by Avery N. Gilbert
}

I hear the sound of a gentle word On the wind that lifts her perfume through the air

I'm pickin' up good vibrations

She's giving me excitations

—The Beach Boys, Good Vibrations, 1966

Who knew that Brian Wilson and Mike Love were olfactory theorists? The idea that the sense of smell operates on the same principle as hearing or vision-namely, vibrations causing neural excitations-has a long pedigree. In 1857, a perfumer named Septimus Piesse placed odors on a musical scale: camphor vibrated one octave above middle C. In 1919, Albert Heyninx proposed that the nose identifies an odor molecule by the selective absorption of light specific to its intramolecular vibrations. In 1937, Malcolm Dyson invoked infrared spectroscopy and the Raman Effect. R.H. Wright's spin in the 1960s was to correlate wave number with psychophysical data, to no avail.

Vibration theory lay dormant for the past three decades largely because it lacks a plausible biological mechanism for converting intramolecular vibrations into neuronal activation. Recently, however, it was resuscitated by a physiologist and perfume critic named Luca Turin. While implausible, Turin's proposal is certainly a delightful potpourri of creativity, conjecture, extrapolation, and isolated observations. And it's brazen: a universal theory of smell based on one man's olfactory impressions. In a grand substitution of ego for psychophysics, Turin claims that Turin's theory successfully predicts odors because they smell the way Turin says they do.

The Emperor of Scent is the story of how Turin arrived at his version of vibration theory, and his trials and tribulations in get-

Avery Gilbert is at the Cranial One Corporation, Upper Montclair, New Jersey 07043, USA. e-mail:avery.gilbert@cranial-one.com ting it published. But this giddy and overwrought account by Chandler Burr is more than a standard scientific biography; it's part hagiography and part legal brief.

Burr portrays Turin as a Goethe-like polymath, a brilliant, intellectually restless, self-educated aesthete. He has a doctorate in physiology but "picked up chemistry on his own", along with physics. He's held appointments at research institutes in France, Russia, the USA and England. Turin is a vivid conversationalist, capable of invoking the Situationists, Noël Coward and Wagner in an anecdote about why he disliked elementary school. We learn that Turin is a sharp dresser and vain about his appearance. He bores easily. His favorite Sauternes is the 1981 Château Lamothe Despujols.

Turin collects perfume and perfumery lore. In 1992, while between jobs, he published Parfums: Le Guide, a collection of perfume reviews written in a hyper-lyrical mode. A typical example: "Après l'Ondée evolves only slightly with time: its central white note, caressing and slightly venomous, like the odor of a peach stone, imposes itself immediately and retains its mystery forever." Turin's acute olfactory sensibilities can detect the heroic creativity lingering in the sad dregs of an antique perfume bottle. $\mathrm{He}$ frequently bemoans the loss of quality and style in contemporary perfumes, as their manufacturers cheapen the ingredients and cater to modern mass-market tastes. For him, the oldies are golden.

With similar nostalgia, Turin rejects the current, receptor-based, 'lock and key' view of olfaction in favor of vibration theory, a notion with Victorian provenance and the patina of history. He dusts off Dyson's paper, updates it with new physics (inelastic electron tunneling), adds some biology (olfactory receptors as spectrometers with NADPH as an embedded energy source) and voila! he has relaunched vibration theory.
Alas, nouveau vibration theory fails to take the world by storm. Their interest piqued by his fragrance reviews, Turin is approached by the "Big Boys", the multinational companies that create and supply perfume for many of the world's most famous brands. They offer him a tantalizing sniff of their vast smell libraries, glimpses of proprietary databases, and invitations to posh parties. They flirt, but ultimately send him off, along with the theory he rode in on. To Burr, this proves that the Big Boys are threatened: they believe Turin's theory is powerful enough to loosen their oligarchic grip on the market.

At the same time, Turin is sandbagged by the entrenched academic establishment. His attempt to publish the theory in a leading British scientific journal is (gasp!) rejected. This deliberate refusal to acknowledge the brilliance of Turin's paper is, according to Burr, clear evidence of "scientific corruption" and a "failure of the scientific process". When later, in a deliberate endrun around peer reviewers, the paper is published by editorial fiat in a specialty journal, Burr detects no failure of scientific process. In the end it doesn't matter: Turin's paper sinks without a ripple.

Burr's book is openly partisan, and his tone swerves unpleasantly between glibness and rancor. When writing about the science, he adopts a self-consciously saccharine style. Electrons are "extremely inquisitive creatures" that "smoosh" around subatomic space. Isotopes are molecular variants akin to Coke and Diet Coke. When describing the reception of Turin's theory, however, Burr's tone develops a hostile edge. Skeptical scientists are described as walking away in disgust, hanging up on phone interviews, and refusing to answer e-mails. Burr borrows a tabloid tactic and offers their noncooperation as proof of a jealous conspiracy against Turin. Science writing has hybridized with ambush journalism.

Humans have roughly 350 functional olfactory receptor genes, yet we can discriminate between thousands of different smells. How this multitude of receptor/ligand relationships forms a sensory code for smell remains to be determined, but there is a broad consensus that receptor binding depends on the shape of the odorant molecule. Against this reality, Emperor of Scent represents a triumphalist account of an unproven alternate theory. In ancient Rome, the honor of a triumph was reserved for an emperor who achieved a glorious victory. Should Turin's conjecture prove correct, he will of course deserve one. But until then, this appears to be a case of premature adulation. 